\title{
WOMEN'S KNOWLEDGE OF THE NUTRITIONAL BENEFITS AND PERCEIVED CONSTRAINTS IN SOYBEAN UTILIZATION IN OYO STATE, NIGERIA
}

\author{
Oyegbami, A. ${ }^{1}$, Fadairo, A. O. ${ }^{2}$ and Oyedokun, M. O. ${ }^{3}$
}

Corresponding author: A. Oyegbami.E-mail: titi_oyegbami@yahoo.com

\section{ABSTRACT}

The study investigated women's knowledge of the nutritional benefits of soybean and its implication for the nutritional status of households in Oyo state. A multistage sampling technique was used to select 129 women for the study. Data were collected via interview schedule on the socio-economic characteristics of women, their knowledge of nutritional benefit of soybean, awareness of soybean by-products and perceived constraints in the utilisation of soybean. Data were analysed using descriptive and inferential (Chi-square) statistic. Results show that women have little knowledge of the nutritional benefits of soybean and majority do not know the by-products of soybean. Major constraints in the utilisation of soybean as identified by the women were high perishability of it products (92.2\%), lack of knowledge of its processing (84.5\%) and lack of market for its product (69\%) among others. Significant relationship exists between education $\left(\chi^{2}=31.494, p=0.000\right)$, crops processed $\left(\chi^{2}=63.990, p=0.000\right)$ and knowledge of nutritional benefit of soybean. It is therefore recommended that awareness be increased on the nutritional benefit of soybean using different medium of information dissemination as this will help increase women's knowledge of the nutritional benefit of soybean and its products, prevent malnutrition, reduce infant mortality and increase the nutritional status of rural household.

Keywords: Nutritional Benefits, Perceived Constraints, Soybean Utilization Women's knowledge.

\section{INTRODUCTION}

The soybean (Glycine max) is a species of legume native to East Asia, widely grown for its edible bean that has numerous uses (Dovemed, 2016), Whole dry soybean contains about 36\% to $56 \%$ protein and up to $18 \%$ fat (Arnerson, 2019). Soybean was first introduced into Nigeria in 1908 but the first successful cultivation was in 1973 with the Malayan variety which was found suitable for commercial production in Benue state in central Nigeria (Fennel, 1996). Nigeria is the largest producer in both western and central Africa since its introduction in the early twentieth century (Dugie, Omoigui, Ekeleme, Bandyopadhyay, Kuma and Kamara, 2009). Soybean is a good source of calcium, iron, zinc, phosphorous, magnesium, thianin,

\footnotetext{
${ }^{1}$ Senior Research Fellow, Agricultural Extension and Rural Development, Institute of Agricultural Research and Training, PMB 5029, Moor Plantation, Ibadan, Nigeria. Mobile phone number +2348033657990. E-mail: titi_oyegbami@yahoo.com.

2 Research Fellow, Agricultural Extension and Rural Development, Institute of Agricultural Research and Training, PMB 5029, Moor Plantation, Ibadan, Nigeria. Mobile phone number +2348036225908. E-mail: anjolaorefadairo@gmail.com

3 Research Fellow, Agricultural Extension and Rural Development, Institute of Agricultural Research and Training, PMB 5029, Moor Plantation, Ibadan, Nigeria. Mobile phone number +2348037267364. E-mail: oyedokunolayemi@hotmail.com
} 
riboflavin, niacin and folacin (Arnarson, 2019 and Natalie, 2019). Attention has recently focussed on the possible role of soybean in the diet for the prevention and treatment of degenerative western diseases. Several studies documented the hypo-cholesterolemic effect of soybean (Erdman Jr, 200); its anti-carcinogenic effect (Kennedy, 1995) and its ability to lower the risk of osteoporosis (Lanou, 2001 and Xi Zheng, 2016).

Soy protein and soy fibre are common ingredients in many food stuff, various kinds of soy protein including soy flour, soy protein concentrate and isolated soy protein are currently used in human and animal foods (Addo and Oguntonna, 1993). Soy protein is used in infant formula and other nutrition products, as ingredients (protein supplement) in feed for animals. Although it is a plant protein, the protein quality is excellent (Slavan, 1991). According to United Nations Food and Agricultural Organisation, soybean have increased in popularity with new soy products like soy milk, soy tofu, soy cheese and oil and so on.

The processing of soybean into various by-products for human and animal consumption involves series of steps; these include threshing, drying, cleaning (removal of impurities and debris from the harvested crop) packaging, storage and final processing into other products (Ugwu and Nwoke, 2011). Processing of soybean into other by-products is very germane in Nigeria where carbohydrate food seems to dominate the diet of its population. In developing countries, integration of processed soybean foods into households' diets therefore, becomes necessary for food and nutrition security.

Women have been known to perform the overwhelming majority of the work in food processing in developing countries and they also produce more than 50 percent of the food worldwide (FAO, 1996). Food processing contributes to food security by reducing food losses, contributing to diversity of diet and supplying important vitamins and minerals (FAO, 2017). In the same vein, women are involved in agricultural production, processing utilization and marketing as well as national economic growth. In their study, Agnes et al. (2001) ascertained that women play important roles as producers of food, managers of natural resources, income earners, and caretakers of household food and nutrition security. They are vital to food security and family well-being and their need for labour-saving and income-generating technologies is acute (Thelma, Feldstein and Duron 2001). In a similar view, FAO (2013) concluded that women are crucial in the translation of the products of a vibrant agriculture sector into food and nutritional security for their households. Implicitly, women should be targeted for any meaningful promotion on utilization and processing technologies because with all the contributions of women to food processing and utilization a significant proportion of farm households still lack access to adequate and balanced nutrition.

The reality in the rural areas is that, though they might not lack food totally but access to the right daily requirement in terms of quality (balanced diet) is a major problem as having an adequate supply of food does not automatically translate into adequate levels of nutrition (FAO, 2017). Achieving well balanced diet food among farm households becomes an issue of concern in the country. According to FAO (2001) food and nutritional security, at individual, household, national, regional, and global levels is achieved when all people, at all times, have physical, social, and economic access to sufficient, safe, and nutritious food to meet their dietary needs and food preferences for a healthy and active life. This study therefore investigated women's knowledge of the nutritional benefits of soybean and its implication on the nutritional status of households. 


\subsection{Objectives}

1) Investigate women's personal characteristics in the study area

2) Examine women's awareness of soybean products

3) Determine women's knowledge of the nutritional benefits of soybean

4) Find out perceived constraints in the utilization of soybean.

\subsection{Research Hypotheses}

Ho1: There is no significant relationship between selected socio-economic characteristics of women and knowledge of nutritional benefits of soybean.

\section{METHODOLOGY}

\subsection{The study area}

The study was carried out in Oyo state, Nigeria. Oyo State is an inland state in south western Nigeria with its capital in Ibadan. It has a total land area of $28,454 \mathrm{~km} 2$ and a population of $5,580,894$ (Wikipedia, 2020). The state is homogeneous mainly inhabited by the Yoruba ethnic group who are primarily agrarian. Oyo state consists of 33 local government areas.

\subsection{Sampling technique}

A multi-stage sampling technique was used to select the population for the study. Two zones out of the four agricultural zones of Agricultural Development programmes (ADP) were purposively selected for the study. Three Local Government Areas (LGAs) in each zone were also purposively selected based on their prominence in soybean production, $20 \%$ of the communities in the LGAs were randomly selected to make a total of twenty-four communities in all. Six women were randomly selected from each of the communities to give a total of 129 women.

\subsection{Data collection and analysis}

Preliminary visits/Pre-intervention survey was done in collaboration with Agricultural Development Programme (ADP) staff to identify communities/villages. A structured interview guide was used to elicit relevant information from women. Data was collected on socioeconomic characteristics of women, their awareness of soybean products, knowledge of the nutritional benefits and perceived constraints in the utilization of soybean. Data was analysed using descriptive statistics such as frequency counts, percentages and mean while chi-square was used to test the relationship that exist between selected socio-economic characteristic and women's knowledge of the nutritional benefits of soybean

\section{RESULTS AND DISCUSSION}

\subsection{Socio-economic characteristics of women}

The socio-economic characteristics of women are presented in Table 1 . The mean age of the women was 50 years and more than half $(67.6 \%)$ were within the age range of 30-50 years. It can be inferred that the women are in their active and productive age. The mean household size 
was 6 persons with $87.6 \%$ having household size of between 1-8 persons per household. This may be useful to households where more hands are needed on the field in terms of labour required. A little above average $(58.1 \%)$ of the women had one form of education or the other; $40.3 \%$ had primary education, $14.7 \%$ had secondary education and $3.1 \%$ had tertiary education which is an indication that more than half of the women are literate. This would help them understand or comprehend and likely adopt any technology that will be beneficial to them. Also, $63.6 \%$ of the women were farmers, $12.4 \%$ were into processing, $14.5 \%$ were traders, $7.8 \%$ were civil servant and $2.4 \%$ were artisans as major occupation. This shows a diversification in the occupation of the women. Almost half of the women (43.3\%) belonged to one association or the other while $56.6 \%$ did not belong to any association, the reason adduced to this is lack of trust among members of these associations. The situation would definitely have negative impact on women's knowledge of soybean especially where group or team work is required, for example in cases of access to loan or information as the case may be.

As regards crops processed by the women, a little above average $(55.8 \%)$ of the women processed cassava into gari, while $33.3 \%$ of the women sold their cassava tubers directly and were not involved in processing according to the women's submission. Only $1.6 \%$ processed cassava into; gari and fufu, gari and soybean, and yam flour respectively and $4.7 \%$ process sobo. It can be concluded that majority of the women do not process soybean into either milk or other soybean products. The observations might be attributed to some problems faced by rural women in processing soybeans in the study area. This corroborates the findings of Ashaye, Adegbulugbe and Sanni (2005) that the problems militating against women in soybean enterprise, as well as other agro-based enterprise such as lack of improved technologies, inadequate contact with extension agents, primitive and labour intensive farm implement which have adverse effect on soybean processing and marketing both at local and industrial levels.

The average monthly income of $45.7 \%$ of the women was $\leq \$ 10,000.00,21.3 \%$ earned between $\$ 11,000.00$ - $\$ 20,000.00 ; 17.1 \%$ earned between $\$ 21,000.00$ - $\$ 30,000.00$ and $12.4 \%$ earned more than $\$ 30,000.00$ while the mean monthly income was $\$ 23,680.00$. The average monthly income can be increased if the women have more knowledge of the nutritional benefits of soybean, it's processing (into different products), inclusion into household diets which will further increase their nutritional status, income as well as improve their standard of living.

Table 1: Personal characteristics of respondents

\begin{tabular}{|l|l|l|l|}
\hline Variable & Frequency & Percent & Mean \\
\hline Age (years) & & & \\
$\leq 30$ & 12 & 9.3 & \\
$31-40$ & 37 & 28.7 & 50.1 \\
$41-50$ & 24 & 18.6 & \\
$>50$ & 56 & 53.4 & \\
\hline Household size & & & \\
$1-4$ persons & 36 & 27.9 & \\
$5-8$ persons & 77 & 59.7 & \\
$>8$ persons & 16 & 12.1 & \\
\hline Educational Status & & & \\
No formal occupation & 54 & 41.9 & \\
\hline
\end{tabular}




\begin{tabular}{|l|l|l|l|}
\hline Primary education & 52 & 40.3 & \\
Secondary education & 19 & 14.7 & \\
Tertiary education & 4 & 3.1 & \\
\hline Major Occupation & & & \\
Farming & 82 & 63.6 & \\
Processing & 16 & 12.4 & \\
Trading & 18 & 14.0 & \\
Civil servant & 10 & 7.8 & \\
Artisan & 3 & 2.4 & \\
\hline Belonging to Association & & & \\
Yes & 56 & 43.4 & \\
No & 73 & 56.6 & \\
\hline Crops processed & & & \\
Cassava into gari & 72 & 55.8 & \\
Cassava into gari \& fufu & 2 & 1.6 & \\
Soybean \&gari & 2 & 1.6 & \\
None & 43 & 33.3 & \\
Rosell(sobo) & 6 & 4.7 & \\
Soymilk & 2 & 1.6 & \\
Yam flour & 2 & 1.6 & \\
& & & \\
\hline Average monthly income (\$) & 55 & 45.7 & \\
$\quad \leq 10,000$ & 32 & 21.3 & $\mathbf{N} 23,680$ \\
$\quad 11,000-20,000$ & 22 & 17.1 & \\
$21,000-30,000$ & 16 & 12.4 & \\
$\quad$ > 30,000 & & & \\
\hline
\end{tabular}

Field survey, 2017

\subsection{Women's knowledge of nutritional benefits of soybean}

Women's knowledge of nutritional benefits of soybean is presented in Table 2. Findings from the study show that women have little or no knowledge of the nutritional benefits of soybean as $93.3 \%$ do not know that soybean can prevent massive number of infant mortality, another 93\% also do not know that soybean can improve the nutritional status of children fed with it, only $10.9 \%$ have the knowledge that soybean is good for both adult and children. About ten percent $(10.1 \%)$ know that soybean is good for pregnant women, $9.3 \%$ have the knowledge that soybean is rich in protein, can reduce the occurrence of low birth weight $(7.8 \%)$, is a solution to malnutrition (7\%), and can be used as a substitute for animal protein. Above all, women have very little knowledge of the nutritional benefits of soybean but they just consume at will. The indication of this finding is that the inclusion and adoption of soybean recipe into household diets was low among women in the area of study. This is in line with the findings of Ogundipe and Osho (1990) that despite the high nutritional value of soybean relative to other legumes, lack of knowledge of its uses has limited the adoption, consumption and production in non-traditional areas of cultivation. 
Table 2: knowledge of the nutritional benefits of soybean $\quad n=129$

\begin{tabular}{|l|l|l|l|l|}
\hline \multicolumn{2}{|l|}{ Knowledge statement } & No(\%) & Mean \\
\hline $\mathbf{1}$ & $\begin{array}{l}\text { It can prevent massive number of infants and child } \\
\text { death }\end{array}$ & $9(7.0)$ & $120(93.0)$ & 0.14 \\
\hline $\mathbf{2}$ & $\begin{array}{l}\text { Soybean can improve the nutritional status of } \\
\text { children fed with it }\end{array}$ & $9(7.0)$ & $120(93.0)$ & 0.14 \\
\hline $\mathbf{3}$ & $\begin{array}{l}\text { Soybean is not only good for children but also for the } \\
\text { adults }\end{array}$ & $14(10.9)$ & $\begin{array}{l}115 \\
(89.9)\end{array}$ & 0.11 \\
\hline $\mathbf{4}$ & Soybean is not good for pregnant women & $13(10.1)$ & $116(89.9)$ & 0.10 \\
\hline $\mathbf{5}$ & Soybean is not as rich in protein as animal meat & $12(9.3)$ & $117(90.7)$ & 0.09 \\
\hline $\mathbf{6}$ & $\begin{array}{l}\text { Soybean intake can reduce the occurrence of low } \\
\text { birth weight among pregnant women }\end{array}$ & $10(7.8)$ & $119(92.2)$ & 0.08 \\
\hline $\mathbf{7}$ & $\begin{array}{l}\text { Soybean has solution to malnutrition in both adult } \\
\text { and children }\end{array}$ & $9(7.0)$ & $120(93.0)$ & 0.07 \\
\hline $\mathbf{8}$ & $\begin{array}{l}\text { Soybean products could be used as animal protein } \\
\text { substitute in human diets }\end{array}$ & $8(0.2)$ & $121(93.8)$ & 0.06 \\
\hline $\mathbf{9}$ & $\begin{array}{l}\text { Micro-nutrient that is mostly deficient in other foods } \\
\text { cannot be supplied by soybean }\end{array}$ & $79(5.4)$ & $122(94.6)$ & 0.05 \\
\hline $\mathbf{1 0}$ & Soybean contains more dangerous fat in food & $4(3.1)$ & $125(96.9)$ & 0.03 \\
\hline
\end{tabular}

Field survey, 2017.

\subsection{Women's awareness of soybean products}

Table 3 presents the awareness of women of soybean products. Result in the table show that of all the selected by-products of soybean presented to the women interviewed, they were only familiar with soymilk $(84.5 \%)$, soy-meat $(33.3 \%)$ and soy-flour $(30 \%)$. Very few were familiar with soy-vegetable soup (20.2\%), Soy-Moinmoin (17.15), soy-gari (17.1\%), soy-akara (9.3\%), soy-ogi $(14 \%)$, soy-yogurt $(7 \%)$ and soy-cheese $(3.1 \%)$. Above all, it can be inferred that women have little awareness of soybean products which may be due to lack of information about the product. Saito and Surling (1993) opined that women have inadequate access to agricultural information and innovation. Access to information is a prerequisite to the adoption and continuous use of a technology, no technology would be accepted if the target population is not aware of such technology and its associated benefits. Similarly, Jack and Tobia (2017) signified that farmers make multiple choices in the agricultural cycle on adoption of products and practices. Taking right decision by households depends so much on the quantum of knowledge they have at their fingertips. Research has identified that throughout the cycle of adoption, a number of information challenges can hinder agricultural technology adoption. There is need for farmers to know that a technology exists for adoption to occur with the belief that it will improve productivity and the understanding of how to use the technology effectively.

Table 3: Women's awareness of soybean products $\quad n=129$

\begin{tabular}{|l|l|l|l|l|}
\hline S/N & Products of soybean & Yes $(\boldsymbol{\%})$ & Mean & Rank \\
\hline $\mathbf{1}$ & Soymilk & $109(84.5)$ & 0.84 & 1 st \\
\hline $\mathbf{2}$ & Soy meat & $43(33.3)$ & 0.33 & 2nd \\
\hline $\mathbf{3}$ & Soy flour & $40(30.0)$ & 0.31 & 3rd \\
\hline $\mathbf{4}$ & Soy vegetable soup & $26(20.2)$ & 0.20 & 4th \\
\hline
\end{tabular}




\begin{tabular}{|l|l|l|l|l|}
\hline $\mathbf{5}$ & Soy moinmoin & $22(17.1)$ & 0.17 & 5 th \\
\hline $\mathbf{6}$ & Soygari & $22(17.1)$ & 0.17 & 5 th \\
\hline $\mathbf{7}$ & Soy akara & $12(9.3)$ & 0.16 & 6 th \\
\hline $\mathbf{8}$ & Soy-ogi & $18(14.0)$ & 0.14 & 7 th \\
\hline $\mathbf{9}$ & Soy yoghurt & $9(7.0)$ & 0.07 & 8 th \\
\hline $\mathbf{1 0}$ & soycheese & $4(3.1)$ & 0.03 & 9 th \\
\hline
\end{tabular}

Field survey, 2017

\subsection{Perceived constraints in the utilization of soybean}

Table 4 presents the result of women's perceived constraints in the utilization of soybean and its by-products. The result reveal that the major constraints in the utilization of soybean and its by-products were high perishability of its products $(92.2 \%)$, lack of knowledge of processing $(84.5 \%)$, low market for products $(69 \%)$ and longer time of processing $(63.6 \%)$. This corroborates the findings of Omotayo et al. (2007) as submitted by some of the women interviewed that soybean processing and marketing are complex practices mostly done by women who engage in difficult aspect of the work due to limited access to technology that will reduce drudgery. Access to information on soybean production and processing will increase women's knowledge of it nutritional benefits and application of this knowledge to household nutrition will prevent malnutrition and other disease, increase household nutrition and possibly income. Reports have shown that the processing of soybean using traditional processing equipment is a major problem in its adoption. These problems in most cases have caused a negative impact in its consumption, its prices as well as its rate of production (Edame and Fonta, 2014). Doss 2003; Oyegbami, Fato and Abada, 2018 in their studies opined that the characteristics of a technology is a precondition for adopting it, triability or a degree to which a potential adopter can try something out on a small scale first before adopting it completely is a major determinant in technology adoption.

Table 4: Perceived constraints in the utilization of soybean

\begin{tabular}{|l|l|l|c|}
\hline constraints & $\begin{array}{l}\text { Major } \\
\text { constraints }\end{array}$ & $\begin{array}{l}\text { Minor } \\
\text { constraints }\end{array}$ & Not a constrain \\
\hline $\begin{array}{l}\text { High perishability of its } \\
\text { products }\end{array}$ & $119(92.2)$ & $10(7.8)$ & - \\
\hline $\begin{array}{l}\text { Lack of knowledge of } \\
\text { processing }\end{array}$ & $109(84.5)$ & $20(15.5)$ & - \\
\hline No market for products & $89(69.00$ & $40(36.4)$ & - \\
\hline Longer time of processing & $82(63.6)$ & $47(36.4)$ & - \\
\hline Non-availability of soybean & $10(7.8)$ & $11(8.5)$ & $107(83.0)$ \\
\hline Non-cultivation of soybean & $31(24.0)$ & $20(15.5)$ & $78(60.5)$ \\
\hline
\end{tabular}

Field survey, 2017

\subsection{Relationship between socio-economic characteristics of women and knowledge of the nutritional benefits of soybean}

Table 5 is the result of chi-square test which shows that a significant relationship exist between education $\left(\chi^{2}=31.494, \mathrm{p}=0.000\right)$ crop processed $\left(\chi^{2}=63.990, \mathrm{p}=0.000\right)$ and knowledge of nutritional benefit of soybean. This implies that knowledge of women about the nutritional 
benefit of soybean is influenced by education which will also definitely affect the type of crop processed by them.

The lack of significant relationship between occupation $\left(\chi^{2}=0.578, \mathrm{P}=0.997\right)$, group association $\left(\chi^{2}=1.314, \mathrm{P}=0.518\right)$ and age $\left(\chi^{2}=1.242, \mathrm{P}=0.941\right)$ and knowledge of nutritional benefit at 0.05 level of significance indicates that occupation, group association and age do not influence knowledge of nutritional benefit. According to Ekong (2003) there is no significant relationship between age and adoption behavior of farmers. Education and crop processed by women is significant to knowledge of nutritional benefit of soybean.

Table 5: Relationship between socio-economic characteristics of women and their knowledge of the nutritional benefits of soybean

\begin{tabular}{|l|l|l|l|}
\hline Variable & Chi-square value & df & P -value \\
\hline Education & 31.494 & 5 & $* 0.000$ \\
\hline Occupation & 0.578 & 6 & 0.997 \\
\hline Crop processed & 63.996 & 7 & $* 0.000$ \\
\hline Group association & 1.314 & 2 & 0.518 \\
\hline Age & 1.242 & 5 & 0.941 \\
\hline
\end{tabular}

*significant at $0.05 \%$

\section{CONCLUSION AND RECOMMENDATION}

Result from the study show that women in the study areas have little knowledge and awareness of the nutritional benefit of soybean and its derivatives and are constrained in its utilisation by some factors among which are high perishability of soybean, lack of knowledge of processing and lack of market for soybean products. Education and products processed by women are significantly related to knowledge of nutritional benefits of soybean.

Based on findings from the study, it is recommended that awareness on soybean be increased by food specialist through different media by extension agents to educate and increase knowledge of rural and urban households on the nutritive value as well as the income generating potentialities of soybean. This will go a long way in popularizing soybean, enhancing child and adult nutrition, empowering women economically and reducing poverty. Government should subsidise soybean processing machines as this will encourage women to process soybean into different products.

\section{REFERENCES}

ADDO, A.A. AND OGUNTONA, C.R.B, 1993. Nutritional Value of Soya beans. Paper Presented at Training Workshop of Extension Workers in Soya Bean Processing and Utilization, FMAWA/RD/UNAAB Soybean Popularisation, April-June 1993.

AGNES, R., QUISUMBING, A.R., RUTH, S. AND MEINZEN-DICK, R.S. 2001. Empowering Women to Achieve Food Security Focus 6. Policy Brief 1 of 12 International Food Policy Research Institute, 2033 K Street, N.W. Washington, D.C. 20006-1002 U.S.A.

ARNERSON, A. 2019. Soybeans 101: Nutritional facts and health effect. Accessed from http://www.healthline.com.

ASHAYE, O.A., ADEGBULUGBE, T. A. AND SANNI, S. 2005. Assessment of soya bean processing technologies in Ilorin East and West Local Government Area. CBN, Abuja. 
DOSS. C.R. 2003. Understanding farm level technology adoption: lessons from CIMMYT's macro survey in Eastern Africa. CIMMYT Economics working paper 03-07, Mexico.

DOVEMED. 2016. Health benefits of soybean. Available from: Dovemed editorial board http://www.dovemed .com.

DUGIE I, Y., OMOIGUI L, O., EKELEME F., BANDYOPADHYAY R., KUMA P.L. AND KAMARA A.Y. 2009. Farmers' guide to soybean production in northern Nigeria. International Institute Tropical Agriculture, Ibadan Nigeria.

ERDMAN JR, J.W. 2000. Soy protein and cardiovascular disease. A statement for health care professionals from the Nutrition Committee of the AHA. Vol. 102 (20):2555-2559.

FENNEL, M.A. 1996. Present status of Research on Edible Legumes in Western Nigeria. Paper Presented at the Fourth Nigerian legume conference, Ibadan, Nigeria. IITA. 99 pp.

FOOD AND AGRICULTURAL ORGANIZATION OF THE UNITED NATIONS - FAO. 2017. Factors and constraints affecting women's roles in food security. Accessed from http//www.fao.org/docrep/x0198e/x0198e03.htm.

FOOD AND AGRICULTURAL ORGANIZATION OF THE UNITED NATIONS (FAO). 2013. Gender and Food Security: Module 1.

FOOD AND AGRICULTURAL ORGANIZATION OF THE UNITED NATIONS (FAO). 1996. FAO Focus: Women and Food Security: Women Hold the Key to Food Security. Rome.

FOOD AND AGRICULTURAL ORGANIZATION OF THE UNITED NATIONS (FAO). 2001. FAO's State of Food Insecurity 2001. Rome: FAO.

JACK, K. AND TOBIA, J. 2017. Seeding success: Increasing agricultural technology adoption through information. IGC Growth Brief Series 012 London: international growth centre.

KENNEDY, A.R. 1995. The evidence of soybean products as cancer preventive agents. J. Nut. 125 (3):733S-743S

LANOU, A.J. 2011. Soy foods: Are they useful for optimal bone health? The Adv. Muskuloskeleton Dis.3(6):293-300.

NATALIE, O. 2019: What to know about soya. Accessed from http://www.medicalnewstoday.com. Assessed on 28/3/2020.

OGUNDIPE, H.O. AND OSHO, S.M. 1990. Development and introduction of improved soybean utilization technology for use in households and small-scale processing enterprises in rural Nigeria. Final report of IITA/IDRC Soybean utilization project (1987 - 1990). (IITA/IAR and T), Ibadan, Nigeria.

OMOTAYO, A.M., OLOWE, V.I.O., FABUSORO, E., BABAJIDE, J.M., OJO, D.K. AND ADEGBITE, D.A. 2007. Commercial demand for soybean in Nigeria, Monograph series \#29, Department for International Development.

OYEGBAMI, A., FATO, B.F. AND ABADA, G.O. 2018. Constraints to women's adoption of improved agricultural technologies introduced by Women in Agriculture in Edo state, Nigeria. Nigerian J. Rur. ext. and Dev. 12:1-18

SAITO, K.A. AND SURLING, D. 1993. Developing agricultural extension for women farmers. World Bank. Discussion paper No 5, pp 20 -25.

SLAVAN, J. 1991. Nutritional benefits of soy protein and soy fibre. Department of food science and nutrition, University of Minnesota, St. Paul 91 (7):816-9

THELMA, R.P., FELDSTEIN, H.S. AND DURON, G. 2001. Empowering Women to Achieve Food Security Technology. Focus 6, Policy Brief 5 of 12. International Food Policy Research Institute, 2033 K Street, N.W. Washington, D.C. 20006-1002, U.S.A 
UGWU, D.S. AND NWOKE, U.M. 2011. Assessment of soybean products, acceptability and consumption in Orumba South local government area of Anambra State, Nigeria. Int. Res J.Agric. Sci \& Soil Sci. 1 (8): 314-325.

XI ZHENG, SUN-KYEONY LEE, AND CHUN, O.K. 2016. Soy isoflavones and osteoporatic bone loss: A review with emphasis on modulation of bone remodelling. J. Med Food 19 (1):1-44. 